\title{
Sebastian Klotz
}

\section{"Were euery thought an eye - Musical actio and the Crisis of Visionary Language in Dowland's Lute Songs}

John Dowland's lute songs abound with references to the senses and with visual metaphors. I would like to argue that these allusions offer clues to the nature of the singing persona and to a paradigmatic shift from visionary language to a poetics of immediate, sensual musical expression. Phrases such as »Were euery thought an eye «, which is the first line of a song published in A Pilgrimes Solace (London 1612), contrast vehemently with another opening line, "Praise blindnesse eies, for seeing is deceit" (The Second Booke, London 1600). If thinking comes close to seeing, why should seeing be deceitful? These two lines encapsulate a transformation in the early modern economy of the senses which supply Dowland with rich imagery and with a new urgency of musical articulation.

The term »visionary language« denotes an important tenet of Medieval and Renaissance thought which implied that truth is utterly linguistic, and, secondly, that human thought has a visual dimension. Language was conceived of as specular, in the sense that thoughts were visible to the mind. This is evident in the tradition of psalmic speech which is regularly imagined as a kind of ideal language that can be visualized. ${ }^{1}$ The words »ideal and »idea« stem from the Greek iedein, "to see. $\varkappa^{2}$ According to Joel Fineman's compelling analysis, the Renaissance was particularly sensitive to the tension between visionary language - the ideal, silent language of the eye (vision), generating a specular truth - and, on the other hand, the vocal, physical language, i.e., utterances that can be heard. ${ }^{3}$

1 Joel Fineman discusses visionary language in his seminal essay "The Turn of the Shrew, «Shakespeare and the Question of Theory, ed. Patricia Parker and Geoffrey Hartman (New York, 1985), pp. 138-159. He illustrates his thesis with an image from Robert Fludd's Tomi Secundi Tractatus Secundus: De Prenaturali Utriusque Mundi Historia (Oppenheim, 1621). Fludd shows an allegory of ideal language on the basis of psalm 63, »In alarum tuarum umbra canam, « in which King David visibly sends a string of letters in the form of a beam of light to an ideal eye in the centre of the sun, in which are inscribed the Hebrew letters for Jehova. The referent Jehova, according to Fineman, is represented was an eye both seeing and seen, « as both "agent and patient of sight. * Verse thus becomes a medium of vision, something Dowland alluded to in »Were euery thought an eye.«

2 Fineman, The Turn of the Shrew (cf. fn. 1), p. 151.

3 Ibid., p. 148. 
This opposition between visual and verbal language in the Renaissance has been gauged by William Shakespeare in his sonnets which no longer employ a specular language as the basis of their epideictic strategies, and which revise visual poetics. Shakespeare characterizes language »as something corruptingly linguistic rather than ideally specular. « ${ }^{4}$ I believe that the same holds true for some of Dowland's lyrics. If one could show that a phrase such as "praise blindnesse eies « is more than just a paradoxical statement, it would have implications for the notion of language in general. The gulf between ideal, spiritual vision and sensual proof is evident in the following excerpts from lyrics set by Dowland:

Praise blindnesse eies, for seeing is deceit,

Bee dumbe vaine tongue, words are but flattering windes,

Breake hart and bleed for ther is no receit,

to purge inconstancy from most mens mindes.

(The Second Booke, 1600)

Tell me true Loue, where shall I seeke thy being, in thoughts or words, in vowes or promise making,

In reasons, lookes or passions neuer seeing, [...]

When thoughts are still unseene and words disguised; vowes are not sacred held, nor promise debt: [...]

Mount then my thoughts, here is for thee no dwelling,

Since Truth and Falsehood liue like twins together:

Beleeue not sense, eyes, ears, touch, taste, or smelling

Both Art and Nature's forc'd: put trust in neyther.

(A Pilgrimes Solace, 1612)

Were euery thought an eye,

And all those eyes could see,

Her subtill wiles their sights would beguile,

And mocke their ielaousie.

Her fires doe inward burne,

They make no outward show.

And her delights amid the dark shades,

Which none discouer, grow.

(A Pilgrimes Solace, 1612)

Relying on Fineman's insights into Shakespeare, one is tempted to assume that Dowland in his lute songs likewise negotiated the crisis of visionary language with a newly-gained intensity of verbal language generated in the moment of musical promuntiatio - in the delivery of the performance. This had profound effects on the reconomy of the senses and paved the way for a melancholic disposition arising from the collapse of visionary language and from the mistrust of

4 Joel Fineman, Shakespeare's Perjured Eye. The Invention of Poetic Subjectivity in the Sonnets (Berkeley, 1986), p. 15. 
the senses. This melancholic disposition turned out to become a major source of artistic creativity. One could go a step further by saying that Dowland explores a paradoxical or even paralyzing actio against the background of fundamental mistrust of both the senses and of specular language. This will allow him to unfold a new poetic subjectivity of the speaking and singing persona. As will be shown, in the final analysis Dowland replaces visionary language by anatomy, by direct references to physical evidence. Thus he can approach the human body as a site unharmed by the distortions imposed by specular truth. If seeing is deceit, then one has to inspect the brains in order to gain trustworthy insights.

Yet, Dowland does not illustrate philosophical doctrine per se. He is a musician in the first place and moulds these shifts from visionary language to paradoxical actio as a musical virtuoso. The texture of his lute songs seem to be almost too accessible, at times even simplistic. This creates an unsettling contrast between the collapse of visionary language and the pleasing appearance of his compositions. This musical wisdom which led him to avoid overtly disruptive structures was governed by his sense of musical and cosmic harmony, which was more than just a metaphor. It was, rather, a powerful guiding motif that regulated the interplay of neo-Platonic doctrine and the rise of genuine early modern experiences.

I would like to proceed not by a comprehensive review of topoi, but focus on three areas in which the shift which has been characterized above becomes most prominent. These areas are firstly, visionary language and anatomy, secondly, paralyzed actio and thirdly, the economy of the senses in general. This brief and preliminary inquiry will build on existing studies on music, melancholy and the emblem tradition, but will for the first time radically expose the interplay between visionary allegorical speech and first-hand tactile and sensual knowledge. The composer cultivated this tension, as it allowed him musically to dramatize an inner experience literally unheard of before.

\section{From visionary language to anatomy}

Dowland himself provides the hint for the unlikely passage from language to anatomy. The second verse of »Praise blindnesse eies» (see above) runs as follows:

And if thine eares false Haralds to thy hart, Conuey into thy head hopes to obtaine, Then tell thy hearing thou art deafe by art, Now loue is art that wonted to be plaine, Now none is bald except they see his braines, Affection is not knowne till one be dead [...] 
If vision fails, there seems to be just one ultimate source of certainty: it is the body not contaminated by the decorum of speech and by ambivalent gesture. The dead body that lies open for inspection and, on the other hand, theological speech and cosmic truth, emerge as the only agencies that can guarantee ssenses and smeaning in a world deprived of its certainties. Dowland slips into the role of the poet-anatomist who explores himself in painful self-dissection and selfdemonstration. Borrowing these terms from Jonathan Sawday's studies on the Body emblazoned in which the author discusses how doubt becomes a matter of poetry, ${ }^{5}$ one can equally state that doubt plays itself out in the auditory anatomy undertaken by Dowland's speaking personae. His permanent references to physical symptoms, his musical emblematics of human tears, his constant evocation of things seen and heard, his recourse of the fragile nature of the human body, are so massive and direct that one can only bear them unless you do not take them for real - although they are described as utterly realistic and trustworthy. This interest in physical symptoms and evidence gained by the senses is an outcome of the crisis of visionary language which brings events within direct physical reach now that the transcendental grasp of an ideal, specular language holds no longer true.

The influential French author Guillaume du Bartas, in His Devine Weekes, addressed the human body, the »devinest Maister-Piece of Art, « ${ }^{6}$ in a manner similar to Dowland's invasive anatomy. As the title suggests, his perspective is a theological one, as the revelation of the sinner man< was »a sacramental, sacrificial act. $\aleph^{7}$ Puzzled by the complexity of the human fabric, Du Bartas poses a series of questions which have a perfect match in a Dowland song:

Shall I the Harts un-equall-sides explaine,

Which equal poize doth equally sustaine?

$[\cdots]$

Or shall I cleave the Lungs, whose motions light,

Our inward heat doo temper day and night $[. .$.$] ?$

$[\ldots]$

Or, shall I rip the stomachs hollowness [...]?

(Du Bartas, The Divine Weeks, I. 282) ${ }^{8}$

5 Jonathan Sawday, The Body Emblazoned. Dissection and the Human Body in Renaissance Culture (London, 1995).

6 The Divine Weeks and Works of Guillaume de Saluste, Sieur du Bartas Translated by Joshua Sylvester (London, 1605), ed. Susan Snyder (Oxford, 1979), vol. 1, p. 276. Cited by Sawday, ibid., p. 96.

7 Sawday, The Body Emblazoned (cf. fn. 5), p. 130.

8 See Sawday, ibid., p. 97. 
This philosophical poem was written in the 1570s and 80s. An English translation was published between 1598 to 1608 , so that it would have been accessible to Dowland either during his stay in Paris (1580 to 1584 ), or later on, in London. The famous song by Dowland that immediately comes to mind equally targets the symptoms of the human body by means of questions:

Shall I sue shall I seeke for grace?

Shall I pray shall I proue?

Shall I striue to a heauenly Ioy,

With an earthly loue?

Shall I think that a bleeding hart

Or a wounded eie,

Or a sigh can ascend the cloudes

To attaine so hie.

(from The Second Booke, 1600)

Besides the explicit physical images, this song portrays a speaking self who literally does not know how to react. This is an exact expression of what I mean by paralyzed or arrested actio, a kind of pronuntiatio of doubt intimately linked to melancholy.

\section{Paralyzed actio}

Before the crisis of visionary language, there clearly were manifestations of poetic despair and longing, but they hardly put themselves forward in the manner of Du Bartas' perplexing gaze into the human body or in Dowland's poetics of doubt, such as in »Shall I sue. Here we witness the devastating effect of doubt as it creeps into human action itself. It is closely tied to melancholy which will leave you in despair either way: if you explore the reasons for the disposition, you are likely to be even more horrified. If you cannot control the reason for the disposition, you continue to be absorbed by a nagging sense of uncertainty. ${ }^{9}$ It becomes increasingly difficult to communicate sincerity. At the same time, this very difficulty became a startling new option which enabled artists to explore in new ways the tension between visual and verbal language, and between sensual data and intellectual convictions.

Dowland was aware of contemporary discourse on melancholy - the proximity of some of his phrases to medical treatises is just too evident. Compare, for instance, Dowland's lines

9 See Sebastian Klotz, „Flow my teares: Melancholische >delectatio im pathetischen Ayre bei John Dowland, «Von sdelectatio bis sentertainment. Das Phänomen der Unterhaltung in der Musik. Musik-Kultur 7, ed. Christian Kaden and Volker Kalisch (Essen, 2000), pp. 53-67. 
And if thine eares false Haralds to thy hart, Conuey into thy head hopes to obtaine, $[\ldots]$

(»Praise blindesse eies«, verse 2)

with a statement from Timothy Bright's Treatise of Melancholie (London, 1586). Bright regards the reasons for the melancholic disposition in the following way:

onely therein lieth the abuse and defect, that the organicall parts which are ordained embassadours, and notaries vnto the mind in these cases, falsifie the report, and deliver corrupt records. ${ }^{10}$

The administrative and legal jargon used by Bright in this statement is interesting: something misfunctions within the sensual paths inside the body. It is a corruptingly linguistic, language-based event, as the "report « and the "records" are being falsified. But these records have not been written by a human hand. They are part of the inner workings of a body whose physiological data processing has gone out of control. One cannot imagine a »language further removed from the text-based, specular language of a visionary eye.

In Dowland's lute songs, the paralyzed actio exposed in the lyrics does not lead to a similar paralysis on the immediate level of actual artistic delivery: here the singing persona is as eloquent as ever, using all the available senses to deliver its subtle message. In »Shall I sue, « the composer undermines the disruptive nature of the text by a swift, apparently easy flow of the melodic line, which hardly leaves time fully to taste the beauty of despair, the aesthetic horror of powerlessness and of suspended action. The musical setting lends the presentation of the song an uncanny sense of closure and coherence absent not from the poetic form, but from the contents of lyrics, which cast a tremulous body in a moment of doubt.

The same multi-layered actio in which the musical coherence challenges the disorienting contents of the lyrics, can be encountered in the examples presented at the beginning of this paper. »Praise blindnesse eies« is a paradoxical statement in itself, »Tell me true Loue s sounds like the appeal for an ultimate answer which apparently cannot be found in the realms of art or nature (see above). We listen to a poetic persona who cannot trust her senses but who fully mobilizes her sensual potential and who absorbs our senses in delivering this message. "Were euery thought an eye « manages to get round outright disappointment but does not get any nearer to real love. Instead, it transforms desire into a flower whose growth we are unable to understand:

10 Timothy Bright, A Treatise of Melancholie (London, 1586), p. 112. Quoted from the facsimile edition in the series The English Experience 212 (Amsterdam and New York, 1969). 


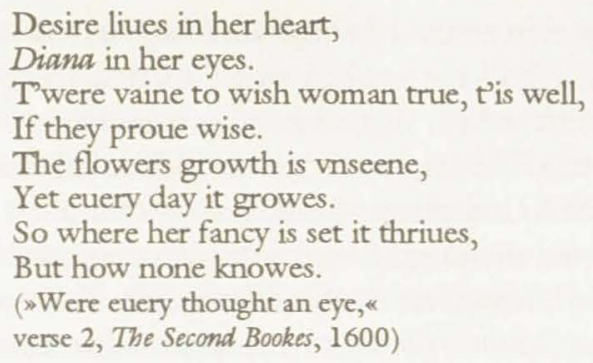

Dowland chose a coranto style for this song, as if quick and cheerful music could dispel the instability of a melancholic mind, as Timothy Bright had believed. ${ }^{11}$

\section{The economy of the senses}

I would now like to tackle the demolition of visionary language from yet another angle. If Dowland's actio is an exploration of the tensions between visual and verbal language, between spiritual thought and sensual experience, this must have had repercussions for the economy of the senses. If vision and visionary language alone cannot guarantee truth, what other agents are there to ease orientation among the passions and bodily symptoms which elude description by familiar linguistic statements? Does the sense of hearing, classified as "the second sense in the Middle Ages and the Renaissance, ${ }^{12}$ supersede vision? What is the role of the lower senses such as smell, taste and touch?

The restructuring of the sensual agenda in the Renaissance led to a specific economy of the senses as it affected »systems of sensory interdependence, hierarchy, transformation, and exclusion« and the ways in which »sensibilities« were constructed. ${ }^{13}$

An initial answer to these questions related to sensual perception needs to take into account the fact that neo-Platonic views not only propagated the theory of visionary language, but that they stressed the role of pronuntiatio - the

11 Linda Phyllis Austem, mNo pill's gonna cure my illk: gender, erotic melancholy and traditions of musical healing in the modern West, * Musical Healing in Cultural Contexts, ed. Penelope Gouk (Aldershot, 2000), p. 123.

12 See The Second Sense. Studies in Hearing and Musical Judgement from Antiquity to the Sepenteenth Century. Warburg Institute Surveys and Texts 22, ed. Charles Burnett, Michael Fend and Penelope Gouk (London, 1991).

13 Quoted from the materials of the Conference Economies of the Senses, held at the Humanities Institute of the University of Chicago in 1996. It was organized by Martha Feldman, Sander L. Gilman, Christopher Looby and Robert S. Nelson. 
role of aural delivery - in terms of energeia. Energeia, conceived of as a divine force that made itself felt in the spoken word, carried with it a kinetic momentum, a physical impulse which actualized the substance of a statement in the form of the delivery. ${ }^{14}$ This is, in fact, the influential doctrine according to which, one evokes the God-given meanings of things by speaking out their names. The role of sensual cognition in this process has been recognized by Renaissance natural philosophers such as Bernardo Telesio. According to this school of thought, »to know « meant to be subjected to the integrity of sensual cognition. Knowledge implied being able to visualize natural forces, which had implications for the new metaphysical perspective of early modern natural philosophy. ${ }^{15}$ This material ingredient of communication adds a crucial facet to our understanding of linguistic semiosis, that largely relies on the intellectual, spiritual component of. Many of the English debates on prosody and on quantification focus on the effectiveness of delivery. Philip Sidney's Apology for Poetry could be interpreted from an »energetic « perspective in that he and his circle acknowledged that syllable lengths were actual, not abstract elements of verse. ${ }^{16}$

Following Gary Tomlinson's insights into Marsilio Ficino's auralist views within a visualist culture ${ }^{17}$ and Kate Van Orden's studies on a "metaphysics of hearing « based on physical, not language-based intellectual responses, ${ }^{18}$ one could tentatively sketch out an auralist, auditory regime of the senses. It does not function like the visual register linked to reason, spirituality and consciousness $;{ }^{19}$ rather it slowly approaches the human intellect through the labyrinths of the ear. Each promuntiatio has to pass through this buffer-zone before its filtered effects reach the heart, then a synonym for the human mind. Perhaps it is from

14 Walter Bernhart, >True versifying. Studien zur elisabethanischen Verspraxis und Kunstideologie. Unter Einbeziehung der zeitgenössischen Lautenlieder. Studien zur englischen Philologie N.F. 29 (Tübingen, 1993), pp. 307-331. See also Sebastian Klotz, sMusic with her silver sound. Kommunikationsformen im Goldenen Zeitalter der englischen Musik. Musiksoziologie 4 (Kassel, 1998), pp. 187-8.

15 Stephan Otto, Renaissance und frühe Neuzeit. Geschichte der Philosophie in Text und Darstellung 3 (Stuttgart, 1984), pp. 220-3.

16 This is the major result of Bernhart's study, see above, fn. 14 .

17 Gary Tomlinson, Music in Renaissance Magic. Toward a Historiography of Others (Chicago, 1993), ch. 4.

18 Kate Van Orden, "An erotic metaphysics of hearing in early modem France, "Musical Quarterly 82.3-4 (1998), special issue Music as heard. Listeners and listening in late-medieval and early modern Europe, ed. Rob C. Wegman, pp. 678-91.

19 Linda Phyllis Austern, "The Siren, The Muse, and the God of Love: Music and Gender in Seventeenth-Century English Emblem Books, "Journal of Musicological Research 18 (1999), p. 103. 
this position in the shadow of the eye $\ll^{20}$ that the ear manages to register human experience differently to the immediate sense of sight. As hearing had been closely connected to invention and discovery, it offered itself to exactly the kind of analytical, penetrating self-discovery Dowland mobilizes for the ear (supported by the sense of touch essential for playing on a plucked instrument), and for the receptive and cognitive process within the listener's ears and mind.

The topos of sounds dwelling in the ear is referred to both in the dedicatory poem to Dowland's Second Booke and in a poem devoted to "Hearing « in John Davies Nosce Teipsum, a collection of poems published in 1599, one year before Dowland's song book.

G. Eastland. To I. Dowlands Lute.

$\mathrm{L}$ vte arise and charme the aire,

V ntill a thousand formes shee beare,

$\mathrm{C}$ oniure them all that they repaire,

I nto the circles of hir eare,

E uer to dwell in concord there,

B y this thy tunes may haue accesse,

E uen to hir spirit whose floweing treasure,

D oth sweetest Harmonie expresse,

$F$ illing all eares and hearts with pleasure

O n earth, observing heauenly measure,

$\mathrm{R}$ ight well can shee iudge and defend them,

$\mathrm{D}$ oubt not of that for shee can mend them.

(dedication to Dowland's The Second Booke, 1600)

To George Eastland, the music has informing powers, capable to lend the mere physical vibrations meaning and aesthetic effect. John Davies describes the precautions taken by nature in order to prevent these effects from becoming too violent:

These wickets of the Soule area plac't on hie

Because all sounds doe lightly mount aloft;

And that they may not pierce too violently,

They are delaied with turnes and windings oft.

For should the voice directly strike the braine,

It would astonish and confuse it much;

Therefore these plaits and folds the sound restraine,

That it the organ may more gently touch.

As streames, which with their winding banks doe play,

Stopt by their creeks, run softly through the plaine,

So in th'Eares' labyrinth the voice doth stray,

and doth with easie motion touch the braine.

20 Ibid. 
It is the slowest yet the daintiest sense.

(John Davies, Nosce Teipsum, London 1599) ${ }^{21}$

Davies addresses the ear as the »organ of delay» and of »deferral. ${ }^{22}$ Further studies of a Renaissance economy of the senses will have to look into the shift from Ficinian notions of music to new experimental approaches. To Ficino, the ear perceives echoes of divine musics in the form of images. ${ }^{23}$ Davies's and Eastland's account of the hearing process involves physical vibrations that can be stored within the ear before they access the spirit. What we see emerge here are new sensual strategies at a time in which the immediacy of experience was no longer exclusively linguistic. These strategies point at the complexity of processes of whearing, auditory cognitions and affective persuasion. $\aleph^{24}$

One could perhaps speculate that both the delay of the ear that shields the spirit and the awareness of an overarching harmony, have their part in the economy of the senses as practised by Dowland. They both act as controlling agencies that lend his utterly intensive actio a sense of coherence and closure. In addition, a religious awareness embraced even the most obvious love lyric in Dowland's Second Booke. As a reminder that not only singing, but playing music on instruments, are activities which ultimately praise God, a psalmic motto is displayed at the top of the frontispiece, which shows a round on Psalm 150: "Praise GOD vpon the Lute and Violl.»

\section{Conclusion}

Dowland provides compelling musical miniatures in which he sensualizes inner experience. It is likely that the crisis of visionary language is paramount to his unprecedented musical exploration of human doubt and despair. The new roles he invents for his singing persona out of the tension between an ideal specular and a sense-related verbal language, are crucial for the shaping of a new subjectivity at a time in which sensual and spiritual borders had become porous. This coincides with a process described by Christian Kaden as the breakdown of mi-

21 Quoted from John Davies, The Works in Verse and Prose, ed. Alexander B. Grosart, vol. 1: The Complete Poems ([Blackburn], 1869), p. 106, by Joel Fineman, "Shakespeare's Ear, "Representations 28 (1989), special issue Essays in Memory of Joel Fineman, p. 12.

22 Fineman, Shakespeare's Ear (cf. fn. 21), p. 12.

23 Tomlinson, Music in Renaissance Magic (cf. fn. 17), p. 120.

24 Linda Phyllis Austern, wThe Conceit of the Minder: Music, Medicine and the Mental Process in Early Modern England, «The Maynooth International Musicological Conference 1995: Selected Proceedings, I. Irish Musical Studies 4, ed. Patrick F. Devine and Harry White (Dublin, 1996), p. 135. 
cro- and macrocosmic harmonia which required that harmony was generated and re-invented by the individual, in the form of a miniature smusical worldk, condensed in individual compositions that legitimize themselves without ontological references to spheres that lie beyond them..$^{25}$

As far as the English tradition is concerned, these processes have articulated themselves primarily in the lute song, which was the genre best equipped to explore the new economy of the senses: composers and performers of lute songs cultivated the actio of paradox, a puzzling auditory anatomy of human action and a modern musical semantics of intimacy. Classical allegorical reflection did not offer enough, neither were the new heuristics of the physical senses mature enough fully to understand and fashion human existence musically. Additionally, testimonies of the eye and ear could contradict each other. Dowland gave these unsettling truths a speakable and singable voice. ${ }^{26}$

25 Christian Kaden, »Abschied von der Harmonie der Welt. Zur Genese des neuzeitlichen Musikbegriffs, « Gesellschaft und Musik. Wege zur Musiksoziologie. Festgabe für Robert H. Reichardt zum 65. Geburtstag. Sociologia Internationalis, Beih. 1, ed. Wolfgang Lipp (Berlin, 1992), pp. 27-53.

26 I would like to thank Richard Wistreich for his inspiring and helpful comments on the written version of my paper. 